\title{
HUKUM SLAM DAN PROBLEMATIKA SOSIAL: TELAAH TERHADAP BEBERAPA HUKUM PERDATA ISLAM DALAM KOMPILASI HUKUM ISLAM DI INDONESIA
}

\author{
Aris \\ IAIN Parepare \\ aris@iainpare.ac.id \\ Muhammad Sabir \\ IAIN Parepare \\ muhammadsabir@iainpare.ac.id
}

\begin{abstract}
Islamic law cannot be separated from the context of the social life of Muslims in Indonesia. This paper discusses the material analysis of the Compilation of Islamic Law which consists of Marriage, Inheritance and Waqf associated with the social problems of Muslims in Indonesia. The compilation of Islamic Laws received juridical justification with Presidential Instruction No. 1 of 1991, is a form of political Islamic law in Indonesia that is less than perfect because it does not go through the legislation of the legislative body and is a shortcut in establishing and positivating Islamic law. The material of KHI, especially marriage and inheritance, is considered inadequate to accommodate the social problems of Indonesian Muslims.
\end{abstract}

Keywords: Social Problematics, Islamic Law, KHI

\begin{abstract}
Abstrak: Hukum Islam tidak bisa dilepaskan dalam konteks kehidupan sosial umat Islam di Indonesia. Tulisan ini membahas tentang analisis materi Kompilasi Hukum Islam yang terdiri dari Pernikahan, Kewarisan dan Perwakafan dikaitkan dengan problematika sosial umat Islam di Indonesia. Kompilasi Hukum Islam mendapatkan justifikasi yuridis dengan Inpres No. 1 tahun 1991, merupakan bentuk politik hukum Islam di Indonesia yang kurang sempurna karena tidak melalui legislasi badan legislatif dan merupakan jalan pintas dalam penetapan dan mempositifkan hukum Islam. Materi KHI terutama perkawinan dan kewarisan dinilai tidak memadai untuk mewadahi problem sosial umat Islam Indonesia.
\end{abstract}

Kata Kunci: Problematika Sosial, Hukum Islam, KHI

\section{PENDAHULUAN}

Hukum Islam yang diberlakukan pada pengadilan agama yang menjadi kompetensi absolutnya sebelum berlakunya Undang-Undang Nomor 3 Tahun 2006 hanya dalam bidang perkawinan, kewarisan dan perwaqafan. Kompilasi Hukum Islam (selanjutnya disingkat KHI) adalah salah satu bentuk upaya penyeragaman pemberlakuan hukum perdata Islam di Indonesia. Pemikiran untuk membentuk KHI bermula dari keberagaman atau ketidaksamaan acuan yang 
Aris dan Muhammad Sabir:

Hukum Islam dan Problematika Sosial: Telaah Terhadap Beberapa

Hukum Perdata Islam dalam Kompilasi Hukum Islam di Indonesia

digunakan dan dipedomani oleh para ulama / hakim penentuan perkara yang berdasar pada hukum Islam sehingga di banyak tempat muncul perbedaanperbedaan. Dengan demikian, KHI muncul sebagai wujud usaha penyeragaman hukum Islam di Indonesia.KHI yang diberlakukan melalui Inpres Nomor 1 tahun 1991 menjelma menjadi produk hukum yang mapan sehingga dijadikan pedoman dan pegangan oleh para hakim pengadilan agama di seluruh Indonesia dalam memutus perkara perkawinan, kewarisan dan perwakafan. Pemikiran untuk membentuk KHI bermula dari keberagaman dan ketidaksamaan pedoman atau acuan yang digunakan oleh para ulama / hakim dalam memutus perkara yang berdasar pada hukum Islam sehingga di banyak tempat muncul perbedaanperbedaan. Dengan demikian KHI muncul sebagai wujud usaha penyeragaman hukum Islam di Indonesia.

Munculnya KHI mewujudkan adanya keseragaman serta kepastian dalam hukum perdata Islam di Indonesia. Akan tetapi munculnya KHI juga punya potensi yang mengakibatkan tumpolnya kreatifitas hakim dalam memeriksa dan memutus perkara. Hal ini disebabkan karena para hakim tidak lagi mengkaji dan merujuk secara langsung pada kitab-kitab sumber yang menjadi rujukan utama dalam pembuatan KHI. ${ }^{1}$ Hampir tak pernah terdengar hakim-hakim agama memutus perkara yang menjadi jurisprudensi baru bagi dunia peradilan agama. Bandingkan dengan putusan para hakim agama sebelum lahir KHI, mereka sangat inovatif dan berbeda-beda putusannya meski kasusnya sama. Perbedaan ini bukan karena subjektifitas, tapi memang hakim selalu memahami kasus yang sama dengan pendekatan dan historisitas yang berbeda. Perbedaan ini mestinya dipahami sebagai kekayaan dan kearifan lokal, bukan dianggap sebagai absennya 'kepastian' dalam hukum Islam. Padahal dengan lahirnya KHI yang bersifat imperatif (dan bukan fakultatif), hukum Islam malah terpasung pada satu pendapat yang tidak selamanya disepakati umat Islam. ${ }^{2}$

Disengaja atau tidak, diskursus keislaman yang marak belakangan ini telah memarjinalkan posisi KHI dari debat utama pemikiran keagamaan. Isu-isu seperti pluralisme, persamaan gender, demokratisasi, HAM dan lain-lain dilepaskan dari konteks hukum nasional. Betul bahwa wacana pemikiran di atas sangat hidup dan 
Aris dan Muhammad Sabir:

Hukum Islam dan Problematika Sosial: Telaah Terhadap Beberapa

Hukum Perdata Islam dalam Kompilasi Hukum Islam di Indonesia

malah menjadi energi positif sebagai titik temu bagi perbedaan ideologis (seperti NU dan Muhammdiyah). Akan tetapi mereka melupakan bahwa umat Islam memiliki fikih yang sudah dipositifkan oleh negara dan sangat berpengaruh bagi kehidupan masyarakat. Dapat dinyatakan bahwa pasal-pasal KHI adalah produk lama, bias gender dan selalu menjadikan perempuan sebagai warga kelas dua. Misalnya, dalam KHI disebutkan bahwa istri tidak memiliki hak untuk mentalak dan merujuk suaminya. Pasal ini jelas sangat ditentang oleh kaum perempuan yang menginginkan persamaan hak di dalam rumah tangga. Belum lagi menyangkut soal poligami, pembagian warisan, hak dan kewajiban suami istri, nikah beda agama dan lain-lain.

Berangkat dari pemaparan tersebut, maka permasalahan pembahasan tulisan ini adalah bagaimana kompilasi hukum Islam dengan problematika sosial di Indonesia. Pokok masalah tersebut dijabarkan dalam sub masalah sebagai berikut: Bagaimana Proses Legislasi Kompilasi Hukum Islam di Indonesia. Bagaimana Analisis Materi Kompilasi Hukum Islam dengan Problematika Sosial di Indonesia?

\section{PEMBAHASAN}

\section{A. Legislasi Kompilasi Hukum Islam}

KHI adalah salah satu produk politik hukum Islam di Indonesia yang telah mendapatkan pengakuan secara yuridis dengan terbitnya Inpres Nomor 1 Tahun 1991. Secara politik KHI sebagai hukum Islam yang diberlakukan di Indonesia tidak sepenuhnya mengalami kesempurnaan karena pemberlakuannya hanya melalui instruksi presiden tidak dan tidak dalam bentuk undang-undang melalui lembaga legislatif. Langkah yang dilakukan tersebut merupakan jalan pintas untuk mempositifkan hukum Islam karena menetapkan hukum islam melalui lembaga atau badan legislatif dalam bentuk rancangan undang undang hukum perdata Islam pada saat itu tidak memungkinkan untuk dilakukan. ${ }^{3}$ Inpres tidaklah sama kekuatan hukumnya dengan undang undang yang mengikat seluruh warga negara. Sekalipun KHI penetapannya hanya dalam bentuk inpres, KHI tetap dijadikan 
Aris dan Muhammad Sabir:

Hukum Islam dan Problematika Sosial: Telaah Terhadap Beberapa

Hukum Perdata Islam dalam Kompilasi Hukum Islam di Indonesia

sebagai rujukan yang dipedomani dalam menangani dan memutuskan perkara oleh para hakim pada lingkungan pengadilan agama.

Hukum Islam adalah hukum Allah atau aturan-aturan yang bersumber dari Allah yang mengatur semua aspek kehidupan manusia. Sekalipun tanpa adanya justifikasi dari badan legislasi atau institusi lainnya, hukum Islam harusnya tetap mengatur dan mengikat kehidupan manusia. KHI adalah produk pemikiran manusia, ia merupakan kumpulan hukum perdata Islam yang terambil dari dalil dalil yang terperinci. Aturan aturan yang termuat dalam KHI merupakan hasil ijtihad ulama Indonesia. Hasil ijtihad atau fiqhi adalah produk pemikiran atau pemahaman terhadap aturan-aturan Allah yang tertulis dalam teks ayat al Qur'an maupun hadis dari Nabi saw. Fiqh itu mengandung kebenaran yang bersifat relatif, fiqhi sifatnya dinamis mengikuti dinamika perkembangan zaman (tempat, waktu situasi dan keadaan). Secara historis, pandangan-pandangan atau pendapatpendapat fiqhi tidaklah pernah menyatu dalam sebuah mazhab tetapi tetapi termuat dalam beberapa atau banyak mazhab fiqhi. Menetapkan hukum Islam atau fiqhi yang terdapat dalam sebuah mazhab tertentu menjadi hukum positif yang sifatnya mengikat menyebabkan timbul masalah tersendiri. ${ }^{4}$

KHI disusun dengan mengutip dari berbagai kitab-kitab fiqhi dari berbagai mazhab fiqhi. KHI adalah kumpulan materi fiqhi yang terambil dari berbagai kitab fiqhi yang ada, tetapi disusun dalam bentuk rumusan bab, pasal dan ayat. Menurut beberapa tim perumus KHI bahwa KHI merupakan unifikasi dan pemositifan hukum perdata Islam di Indonesia, yaitu mempositifkan hukum perdata Islam secara sistematis dalam kitab hukum ${ }^{5}$.

KHI secara keseluruhan terdiri dari 229 pasal yang dikelompokkan ke dalam tiga buku. Buku satu tentang perkawinan terdiri dari sebelas bab dan 170 pasal. Buku dua tentang hukum kewarisan terdiri dari enam bab, bab satu ketentuan umum, bab kedua ahli waris, bab ketiga besarnya bahagian, bab keempat aul dan rad, bab kelima wasiat dan bab keenam tentang hibah. Buku dua ini dimulai dari pasal 171 sampai pasal 214. Atau terdiri 44 pasal. Buku tiga tentang hukum perwakafan yang terdiri dari 6 bab dimulai dari pasal 215 sampai pasal 229 atau 15 pasal. 
Aris dan Muhammad Sabir:

Hukum Islam dan Problematika Sosial: Telaah Terhadap Beberapa

Hukum Perdata Islam dalam Kompilasi Hukum Islam di Indonesia

Penyusunan KHI dan menjadikannya sebagai hukum positif di Indonesia bertujuan untuk: pertama, sebagai pelengkap pilar pengadilan agama. Kedua, sebagai bentuk penyamaan persepsi dalam menerapkan hukum. Ketiga, KHI diharapkan sebagai media untuk menjembatani atau mempersempit jurang perbedaan dalam masalah hukum perkawinan, kewarisan dan perwakafan. Keempat, untuk menghilangakan pemahaman yang menganggap bahwa hukum Islam atau hukum agama itu privat affair (urusan pribadi) yang tidak bisa dicampuri oleh orang lain apalagi oleh negara atau penguasa. Penyusunan KHI adalah bentuk hadirnya institusi negara dalam pelembagaan hukum Islam di Indonesia. $^{6}$

Menurut beberapa kajian secara akademik bahwa KHI lebih banyak mengadopsi pandangan keagamaan klasik serta pendapat-pendapat fikih tanpa mempertimbangkan secara empiris kondisi masyarakat Islam Indonesia. Aspek kemaslahatan umat Indonesia kurang mendapatkan pertimbangan dalam menyusun materi-materi KHI. Hal tersebut terjadi disebabkan karena penyusunan KHI dinilai hanya memindahkan penjelasan-penjelasan atau pendapat para fuqaha klasik tanpa adanya kajian terhadap kepentingan, keperluan dan kebutuhan umat Islam Indonesia. KHI tidaklah bersumber dari karifan lokal masyarakat Islam Indonesia. $^{7}$

KHI tidaklah sepenuhnya digali dari realitas empiris Indonesia, tetapi banyak "mengangkut" penjelasan normatif tafsir agama klasik, dan tidak ada pertimbangan kemanfaatan umat Islam di Indonesia. mempertimbangkan kemaslahatan bagi umat Islam Indonesia. KHI mengutip hampir semua pandangan fikih klasik dengan sempurna. KHI tidaklah menjadi representasi dari keperluan atau kebutuhan umat Islam Indonesia, hal ini diakibatkan karena ia tidaklah digali secara menyeluruh dari kearifan lokal masyarakat Indonesia. ${ }^{8}$

Mensakralkan fikih merupakan hal yang tentunya tidak diinginkan oleh para pemikir atau ahli fikih termasuk fuqaha (para ahli fikih) klasik. Menurut penilaian beberapa pemikir Islam bahwa beberapa aspek tidak relevannya fikih klasik karena diatur dalam kondisi kultur dan imajinasi sosial yang tidak sama.. KHI dalam beberapa pasalnya disinyalir berpotensi sebagai penghambat kemajuan 
Aris dan Muhammad Sabir:

Hukum Islam dan Problematika Sosial: Telaah Terhadap Beberapa

Hukum Perdata Islam dalam Kompilasi Hukum Islam di Indonesia

demokrasi di Indonesia. Jika beberapa pasal tersebut dibiarkan tetap ada, maka KHI akan terus menumbuhkan praktik diskriminasi di masyarakat khususnya terhadap.

Sejak mula KHI tidak memadai untuk mewadai keragaman aliran fikih yang ada. KHI hanya berfungsi sebagai penyeragaman (unifikasi) hukum Islam dan celakanya digunakan para hakim agama secara instan untuk memutus perkara perdata Islam. Di sana-sini terlihat banyak pasal yang ketinggalan zaman. Padahal dalam bidang hukum, umat Islam memang dikenal tidak pernah bisa disatukan dalam satu payung. Akan tetapi, KHI sudah lahir dan dipraktikkan hampir lima belas tahun di Indonesia. Sebagai kekayaan khazanah fikih umat Islam, ia harus dipandang sebagai produk ijtihadiyyah umat Islam pada zamannya. ${ }^{9}$ Counter Legal Draft (selanjutnya disingkat CLD) KHI yang diajukan oleh Dr Siti Musdah Mulia dan kawan-kawan menunjukkan adanya perbedaan semangat zaman itu. Hampir seluruh pasal-pasal yang ditawarkan CLD berkaitan dengan perkawinan bertolak belakang dengan KHI. Seperti dalam poligami, KHI membolehkan dengan persyaratan, sedangkan CLD mutlak mengharamkan. Padahal sebagai sebuah revisi dan penyempurnaan, RUU ini mestinya tidak perlu mendapat penolakan begitu tajam. ${ }^{10}$

Membandingkan isi CLD dengan KHI seolah seperti melihat perdebatan panjang antara Islam liberal dan Islam tradisional. Dua mazhab ini tidak bisa bertemu dalam satu suara, karena tolok ukur dan paradigmanya yang berbeda. Islam liberal menganut asas progresif, sementara yang lain setia dengan status quo. Problemnya adalah Indonesia dikuasai oleh umat Islam yang konvensional. Sementara Islam progresif berjumlah minoritas, meski menguasai opini publik.

\section{B. Kompilasi Hukum Islam dan Problematika Sosial}

Seiring dan seirama dengan berkembangnya zaman serta adanya dinamika masyarakat di antaranya berdampak pada adanya prrubahan-perubahan pada pola interaksi sosial manusia yang mengakibatkan munculnya berbagai permasalahan sosial. Secara umum permasalahan atau isu-isu tersebut tidak tertampung dengan baik dalam KHI. Masalah sosial yang dimmaksudkan adalah masalah 
Aris dan Muhammad Sabir:

Hukum Islam dan Problematika Sosial: Telaah Terhadap Beberapa

Hukum Perdata Islam dalam Kompilasi Hukum Islam di Indonesia

ketidakadilan serta diskriminasi yang terdapat pada dua tema besar atau materi pokok dari KHI (hukum perkawinan dan kewarisan). Selain itu, masih banyak persoalan penting yang tidak terserap dalam aturan perwakafan pada KHI. ${ }^{11}$

1. Analisis Dalam Bidang Perkawinan

Pada bidang hukum perkawinan, harus fair diakui bahwa dalam KHI terdapat beberapa pasal yang problematis dari sudut pandang keadilan relasi lakilaki dan perempuan. Di antara masalah-masalah yang kurang mendukung semangat keadilan tersebut antara lain: batas usia pernikahan, wali nikah, saksi nikah, hak dan kewajiban suami isteri, nusyuz, poligami, dan nikah beda agama. Pasal-pasal yang dinilai sarat dengan ketidakadilan tersebut dapat dijelaskan sebagai berikut: Pertama, batas usia minimal nikah yang diatur dalam pasal 15 ayat (1). Pasal ini dianggap tidak adil karena telah mematok usia minimal perempuan boleh menikah lebih rendah dari usia laki-laki. Pasal ini jelas memperlakukan laki-laki dan perempuan secara diskriminatif, yakni semata-mata didasarkan pada kebutuhan dan kepentingan laki-laki (ideologi patriarkhis).

KHI pada beberapa pasalnya tentang perkawinan mesti diakui mengadung masalah dari aspek keadilan hubungan antara laki-laki dengan perempuan. Di antara permasalahan yang bertentangan dengan semanga keadilan relasi laki laki dan perempuan tersebut adalah usia minimal menikah, wali dan saksi nikah, hak dan kewajiban dalam pernikahan (suami dan isteri), nusyuz, poligami, serta perkawinan beda agama. ${ }^{12}$ Pasal-pasal yang dianggap penuh ketidakadilan tersebut dapat dijelaskan sebagai berikut: Pertama, usia minimum untuk menikah diatur dalam Pasal 15 ayat (1). Pasal ini dinilai tidak adil karena telah menetapkan usia minimum bagi perempuan untuk menikah lebih rendah dari pada laki-laki. Pasal ini dengan jelas mengandung diskriminasi yaitu dengan mendasarkan pada kebutuhan dan kepentingan laki laki (ideologi patriarki).

Kedua: tentang perwalian dalam perkawinan.. Penjelasan pembahasan perwalian atau wali nikah dimuat secara berurutan mulai dari Pasal 19 sampai Pasal 23. Pasal-pasal yang menjelaskan tentang wali nikah yang memimiliki kencenderungan yang bias terhadap gender yaitu Pasal 19 dan 20 ayat (1) serta ayat 21 (1). Hak perwalian hanya dimiliki oleh laki-laki saja, dan tidak ada celah 
Aris dan Muhammad Sabir:

Hukum Islam dan Problematika Sosial: Telaah Terhadap Beberapa

Hukum Perdata Islam dalam Kompilasi Hukum Islam di Indonesia

bagi seorang perempuan atau ibu untuk menjadi wali untuk perkawinan putrinya ketikan misalnya ayah tidak ada atau berhalangan untuk menjadi wali, maka hak perwalian berpindah ke kakek. Sekiranya kakek juga tidak bisa menjadi wali, hak perwalian juga tidak otomatis berpindah ke tangan ibu, melainkan ke anak lakilaki (saudara laki-laki dari perempuan yang akan menikah). Hierarki perwalian ini diatur dalam Pasal $21 \mathrm{KHI}$ dengan menutup sama sekali kesempatan perempuan menjadi wali. Dengan demikian, harus ditekankan dalam praktiknya bahwa wali nikah dalam KHI semestinya tidaklah antara laki-laki dengan perempuan, sehingga kalau laki laki memiliki kewenanga untuk menikahkan dirinya dan memiliki otoritas sebagai wali dalam perkawinan maka perempuan juga semestinya memiliki hal yang sama.

Ketiga, tentang saksi. Ketentuan tentang saksi dalam pernikahan diatur dalam pasal 24,25, dan 26. Namun, yang dinilai bias jender hanyalah pasal 25 saja yang menutup sama sekali kemungkinan perempuan untuk menjadi saksi pernikahan. Dengan menggunakan parameter kesetaraan gender, maka semestinya laki dan perempuan mempunyai peluang yang sama untuk tampil sebagai saksi nikah. Keempat, kepala rumah tangga hanya disandangkan pada pundak seorang suami, dan tidak pada isteri. Pasal 79 KHI mengatakan suami adalah kepala keluarga dan isteri adalah ibu rumah tangga. Sebagaimana fikih pada umumnya, KHI tidak pernah mempertimbangan kapabilitas dan kredibilitas isteri untuk memangku status kepala keluarga. Jabatan "kepala keluarga" telah diberikan secara gratis dan otomatis kepada para suami.

Ketiga, pengaturan tentang saksi. Pasal 24, 25 dan 26 mengatur ketentuan yang berkaitan dengan saksi dalam perkawinan. Namun yang dianggap bias gender hanyalah Pasal 25 yang sepenuhnya menutup kemungkinan perempuan menjadi saksi perkawinan. Kalau parameter kesetaraan gender yang digunanakan maka laki-laki dan perempuan seharusnya memiliki kesempatan yang sama untuk tampil sebagai saksi perkawinan. Keempat: Bahwa kepala keluarga bertumpu pada pundak suami saja, bukan pada istri. Pasal 79 KHI menyatakan bahwa suami adalah kepala keluarga dan istri adalah ibu rumah tangga. Seperti halnya kajian fikih pada umumnya, kemampuan dan kredibilitas seorang istri tidaklan menjadi 
Aris dan Muhammad Sabir:

Hukum Islam dan Problematika Sosial: Telaah Terhadap Beberapa

Hukum Perdata Islam dalam Kompilasi Hukum Islam di Indonesia

pertimbanga dalam KHI menjadikan perempuan sebagai kepala keluarga. Jabatan "kepala keluarga" adalah sesuatu hak otomatis dan diberikan secara gratis kepada suami dalam rumah tangga.

Kelima, pengaturan nusyûz dalam KHI ada terdapat dalam pasal 84 ayat (1). Namun demikian, dalam persoalan nusyûz ini KHI masih terlihat bias jender. Sebab, masalah nusyûz dalam KHI hanya berlaku bagi pihak perempuan, sementara laki-laki atau suami yang mangkir dari tanggungjawabnya tidak diatur dan tidak dianggap nusyûz. Oleh sebab itu, pasal ini terlihat mengekang kebebasan hak-hak perempuan dan tidak mendudukkan hubungan suami isteri secara setara.

Kelima, pengaturan nusyûz dalam KHI ada dalam Pasal 84 ayat (1) Namun dalam kasus nusyûz ini, KHI masih terkesan bias gender. Persoalannya adalah masalah nusyûz dalam KHI hanya berlaku untuk perempuan, sedangkan laki-laki atau suami yang melalaikan tanggung jawabnya tidak disebut dalam KHI serta tidak dianggap sebagai nusyûz. Karenanya, tampaknya pasal ini membatasi kebebasan hak perempuan dan tidak menyamakan kedudukan suami dengan istri. Di samping itu, dalam KHI juga belum mengatur tentang persoalan-persoalan kontemporer dalam masalah perkawinan seperti nikah lewat telepon atau internet.

2. Analisis dalam Bidang Kewarisan

Dalam bidang kewarisan KHI juga tidak mencerminkan keadilan. Dalam hukum kewarisan, ketentuan-ketentuan hukum KHI tampak mengabaikan hak-hak anak yang sedang dalam kandungan. KHI hanya memperhitungkan bagian anak yang telah lahir. Padahal, anak yang sedang dalam kandungan justru memiliki beban yang lebih berat, baik dari aspek psikologis maupun finansial. Oleh karena itu, sudah selayaknya KHI merumuskan konsep tentang pembagian warisan bagi anak yang sedang dalam kandungan. Ketidakadilan lain terlihat pada pasal 172 KHI yang diantaranya menyatakan bahwa bayi yang baru lahir atau anak yang belum dewasa, beragama menurut ayahnya atau lingkungannya. Secara implisit, pasal ini menyatakan bahwa agama ibu tidak bernilai sama sekali pada anaknya, baik dalam pandangan masyarakat maupun dalam pandangan Tuhan. Padahal, posisi ibu dalam keluarga sangat penting sebagai pendidik dan perambah masa 
Aris dan Muhammad Sabir:

Hukum Islam dan Problematika Sosial: Telaah Terhadap Beberapa

Hukum Perdata Islam dalam Kompilasi Hukum Islam di Indonesia

depan anak-anaknya. Ini tidak saja mengabaikan peran dan posisi ibu dalam keluarga dan amsyarakat, tetapi juga menafikan agama yang dianut ibu di hadapan anak-anaknya.

Dalam hukum waris, ketentuan hukum dalam KHI seolah olah mengabaikan hak-hak anak dalam kandungan. KHI hanyalah memperhitungkan bagian dari anak-anak yang telah lahir. Padahal, bayi dalam kandungan memiliki beban yang lebih berat, baik secara psikologis maupun finansial. Olehnya itu, sangat penting bagi KHI untuk merumuskan konsep tentang pembagian harta warisan kepada anak-anak di dalam kandungan. Hal lain yang dinilai tidak adil terdapatdalam pada Pasal 172 KHI yang menyebutkan bahwa anak yang baru lahir atau belum dewasa mempunyai agama menurut agama ayahnya atau lingkungannya. Secara tersirat pasal ini menyatakan bahwa agama seorang ibu sama sekali tidak memiliki nilai bagi anaknya, baik dimata masyarakat maupun dimata Tuhan. Padahal tempat ibu atau peran dalam keluarga sangat penting sebagai guru dan penentu masa depan anak-anaknya. Hal ini tidak hanya mengabaikan peran dan kedudukan ibu dalam keluarga dan masyarakat, tetapi juga meniadakan agama yang dianut ibu di depan anak-anaknya.

Hal yang sama juga terjadi pada Pasal 186 KHI. Pasal ini dengan jelas menyatakan bahwa anak-anak yang lahir di luar nikah hanya memiliki hubungan kewarisan dengan ibu dan keluarga ibu. Sedangkan status anak yang lahir karena kawin siri tidak diatur dalam hubungan waris. Oleh karena itu, penting untuk mempertimbangkan kembali definisi apakah perkawinan itu sah atau tidak.

Selain bernuansa ketidakadilan, undang-undang waris juga mengandung banyak kendala teknis yang sulit diterapkan. Hambatan teknis tersebut antara lain terdapat pada Pasal 192 dan 193 yang tidak secara eksplisit menjelaskan mana yang 'awl dan mana yang radd, dan jika tidak segera ada penjelasan, tentu akan sulit bagi hakim di pengadilan untuk menyelesaikan masalah waris keluarga muslim.

3. Analisis Bidang Hibah, Wasiat dan Perwakafan

Dalam bidang hibah pada Bab V dan bab VI tidak ada penjelasan terperici tentang pengertian atau defenisi wasiat dan hibah. Mendefenisikan kedua istilah 
Aris dan Muhammad Sabir:

Hukum Islam dan Problematika Sosial: Telaah Terhadap Beberapa

Hukum Perdata Islam dalam Kompilasi Hukum Islam di Indonesia

ini sangatlah penting karena adanya kesamaan dalam pelaksanaan wasiat ataupun hibah. Sementara itu terkait dengan hukum wakaf, KHI belum bisa dikatakan ideal karena masih banyak hal penting yang belum diakomodasi, di antaranya adalah pemberian wakaf non muslim yang perlu mendapatkan tempat di KHI mengingat ada beberapa kasus yang mengindikasikan hal tersebut mungkin saja terjadi. KHI setidaknya dapat mengkonfirmasi apakah non-Muslim dapat menyumbangkan aset mereka untuk kepentingan Muslim atau tidak. Aturan mengenai wakaf uang tunai juga harus dipahami di KHI. Hal ini dikarenakan pesatnya perkembangan dunia perbankan yang begitu pesat, sehingga visi dan cara pandang masyarakat dalam "menginvestasikan" asetnya demi Allah juga mengalami perubahan. Misalnya, aturan mengenai seseorang, sekelompok orang, atau badan usaha yang bermaksud menyumbangkan uangnya dalam bentuk deposito, kemudian bagi hasil dari simpanan tersebut digunakan untuk membantu korban bencana alam atau untuk membayar biaya pendidikan kepada orang miskin. Wakaf dalam bentuk ini tentunya sangatlah memiliki manfaat dan bersesuaian dengan tujuan utama wakaf dalam Islam.

\section{PENUTUP}

KHI yang sudah lahir dan dipraktekkan yang menjadi pegangan para hakim dalam masalah perkawinan, kewarisan dan hibah dinilai tidak memadai untuk mewadahi keragaman aliran fikih yang ada. KHI hanya berfungsi sebagai penyeragaman (unifikasi) hukum Islam. KHI hanya memindahkan produk fiqhi klasik dan sudah tidak relevan laju perkembangan zaman.

Isu-isu kontemporer seperti pluralisme, persamaan gender, demokratisasi, HAM dan lain-lain memarjinalkan posisi KHI. Pembaruan KHI tidak hanya memindahkan al Quran, hadis serta pendapat ulama ke dalam pasal-pasal tetapi juga perlu melihat realitas empiris dan kearifan lokal yang berbeda-beda serta mepertimbangkan isu-isu kontemporer. 
Aris dan Muhammad Sabir:

Hukum Islam dan Problematika Sosial: Telaah Terhadap Beberapa

Hukum Perdata Islam dalam Kompilasi Hukum Islam di Indonesia

\section{Catatan Akhir}

${ }^{1} \mathrm{Abu}$ Rokhmad dan Umar Ma'ruf, Menggagas KHI Baru yang Progresif, dalam http://www.suaramerdeka.com/harian/0410/22/opi04.htm.

${ }^{2}$ Suadi, Amran. "Perkembangan Hukum Perdata Islam di Indonesia (Aspek Perkawinan dan Kewarisan)." Jurnal Yuridis 2.1 (2017): h. 2-3.

${ }^{33}$ Moh. Mahfud MD, Peradilan Agama dan Kompilasi Hukum Islam Dalam Tata Hukum Indonesia (Yogyakarta: UII Press, 1993), h. 66-67.

${ }^{4}$ Hatta, Akrama. "Daya Serap Hukum Islam di Indonesia pada Bidang Privat." NUKHBATUL'ULUM: Jurnal Bidang Kajian Islam 3.1 (2017): 12-18.

${ }^{5}$ Moh. Mahfud MD, Politik Hukum Di Idonesia (Jakarta: LP3ES, 1998), h. 70.

${ }^{6}$ Moh. Mahfud MD, Politik Hukum Di Idonesia , h. 70-78.

${ }^{7}$ Ghofur, Abdul, and Sulistiyono Sulistiyono. "Peran ulama dalam legislasi modern hukum Islam." Asy-Syir'ah: Jurnal Ilmu Syari'ah dan Hukum 49.2 (2015): 265-297.

${ }^{8}$ Keri, Ismail. "Legislasi Hukum Keluarga Islam Berdasarkan Kompilasi Hukum Islam." Ekspose: Jurnal Penelitian Hukum dan Pendidikan 16.2 (2019): h. 361-375.

${ }^{9}$ Hikmatullah, Hikmatullah. "Selayang Pandang Sejarah Penyusunan Kompilasi Hukum Islam Di Indonesia." Ajudikasi: Jurnal Ilmu Hukum 1.2 (2017).

${ }^{10}$ Mulia, Muji. "PEMBAHARUAN HUKUM ISLAM DI INDONESIA (Analisis Historis tentang Kompilasi Hukum Islam)." Jurnal Ilmiah Islam Futura 7.1 (2018): 64-85.

${ }^{11}$ Pokja Pengarusutamaan Gender Departemen Agama RI, Menuju Kompilasi Hukum Islam (KHI) Indonesia Yang Adil Gender

${ }^{12}$ Islamy, Athoillah. "Eksistensi Hukum Keluarga Islam di Indonesia dalam Kontestasi Politik Hukum dan Liberalisme Pemikiran Islam." Al-Istinbath: Jurnal Hukum Islam 4.2 (2019): 161-176.

\section{DAFTAR PUSTAKA}

Anwar, M. Syafi'i. Pemikiran dan Aksi Islam Indonesia: Sebuah Kajian Politik Tentang Cendekiawan Muslim Orban. Jakara: Paramadiana, 1995.

Attamimi, A. Hamid. Kedudukan KHI dalam Sistem Hukum Nasional, Suatu Tinjauan dari Sudut Pandang Perundang-undang, dalam Amrullah ahmad (ed), Dimensi Hukum Islam dalam Sistem Hukum Nasional. Jakarta: Gema Insani Press, 1996.

Aris, Aris. "Penegakan dan Penerapan Hukum Islam di Indonesia (sebuah Analisis Pertimbangan Sosiologis dan Historis)." DIKTUM: Jurnal Syariah dan Hukum 13.1 (2015): 40-47.

Efendy, Bachtiar. Islam dan Negara, Transformasi Pemikiran dan Praktik Politik Islam di Indonesia. Jakarta : Paramedia, 1998. 
Aris dan Muhammad Sabir:

Hukum Islam dan Problematika Sosial: Telaah Terhadap Beberapa

Hukum Perdata Islam dalam Kompilasi Hukum Islam di Indonesia

Fikri, Fikri, et al. "Kontekstualisasi Cerai Talak dalam Fikih dan Hukum Nasional di Indonesia." Al-Ulum 19.1 (2019): 151-170.

Ghofur, Abdul, and Sulistiyono Sulistiyono. "Peran ulama dalam legislasi modern hukum Islam." Asy-Syir'ah: Jurnal Ilmu Syari'ah dan Hukum 49.2 (2015).

Haika, Ratu. "Hukum Kewarisan Islam di Indonesia (Analisis terhadap Buku II Kompilasi Hukum Islam)." Mazahib 4.2 (2007).

Hatta, Akrama. "Daya Serap Hukum Islam di Indonesia pada Bidang Privat." NUKHBATUL'ULUM: Jurnal Bidang Kajian Islam 3.1 (2017).

Heifer, Johanes den dan Syamsul Anwar (ed), Islam Negara dan Hukum, dalam Jurnal INIS, Jakarta:INIS, 1993.

Hikmatullah, Hikmatullah. "Selayang Pandang Sejarah Penyusunan Kompilasi Hukum Islam Di Indonesia." Ajudikasi: Jurnal Ilmu Hukum 1.2 (2017).

Islamy, Athoillah. "Eksistensi Hukum Keluarga Islam di Indonesia dalam Kontestasi

Politik Hukum dan Liberalisme Pemikiran Islam." Al-Istinbath: Jurnal Hukum Islam 4.2 (2019).

Keri, Ismail. "Legislasi Hukum Keluarga Islam Berdasarkan Kompilasi Hukum Islam." Ekspose: Jurnal Penelitian Hukum dan Pendidikan 16.2 (2019).

Mahfud MD, Moh., Politik Hukum Di Idonesia, Jakarta: LP3ES, 1998.

Mahfud MD, Moh., Peradilan Agama dan Kompilasi Hukum Islam Dalam Tata Hukum Indonesia. Yogyakarta: UII Press, 1993.

Mulia, Muji. "PEMBAHARUAN HUKUM ISLAM DI INDONESIA (Analisis Historis tentang Kompilasi Hukum Islam)." Jurnal Ilmiah Islam Futura 7.1 (2018).

Raharjo, Satjipto. Hukum dan Masyarakat, Bandung Angkasa.

Suadi, Amran. "Perkembangan Hukum Perdata Islam di Indonesia (Aspek Perkawinan dan Kewarisan)." Jurnal Yuridis 2.1 (2017).

Pokja Pengarusutamaan Gender Departemen Agama RI, Menuju Kompilasi Hukum Islam (KHI) Indonesia Yang Adil Gender.

Sunggono, Bambang. Hukum dan Kebijakan Publik, Jakarta Sinar Grafika, 1994.

Wingjosoebroto, Soetanyo. Dari Hukum Kolonial ke Hukum Nasional, Jakarta : Raja Grafindo, 1994.

Zaki, M. "Arah Legislasi Hukum Islam di Indonesia dalam Perspektif Interaksi Agama dan Negara." MIQOT: Jurnal Ilmu-ilmu Keislaman 39.1 (2015).

http://www.suaramerdeka.com/harian/0410/22/opi04.htm. 